\title{
Şanlıurfa'da bitki koruma ürünü satış yerlerinde çalışanlarda nörolojik ve psikiyatrik semptomlar ve ilişkili faktörler
}

\author{
Burcu Beyazgül1', Zeynep Şimşek², Suna Sarıkaya ${ }^{3}$ \\ ${ }^{1}$ Harran Üniversitesi Tıp Fakültesi, Halk Sağlı̆̆ ABD, Şanlıurfa \\ 2 İstanbul Bilgi Üniversitesi, İstanbul \\ ${ }^{3}$ Antalya Atatürk Devlet Hastanesi, Antalya
}

\section{Öz}

Amaç: Ruhsal ve nörolojik bozukluklar dünyada öncelikli halk sağllğı sorunlarından biridir. Bu çalışmada, Şanlıurfa il merkezine kayıtlı bitki koruma ürünü (BKÜ) satışı yapan işyerlerinin yasal düzenlemelere uygunluğunu belirleyerek, çalışanların nöro-psikiyatrik semptomlarını ve bu semptomlarla ilişkili faktörleri belirlemek amaçlanmıştır. Yöntem: Kesitsel tipteki bu araştırmada Harran Üniversitesi Tıp Fakültesi etik kurul onayı alınmıștır. Araştırmanın evrenini, 2014 yılında Şanlıurfa Gıda Tarım ve Hayvancılık İl Müdürlügü'nden alınan listeye göre, il merkezi ve merkeze bağlı köylerde olmak üzere il merkezinde bulunan toplam 119 pestisit satış yeri oluşturmuştur. Çalışma tarama çalışması niteliğinde olup, tüm işyerlerine ulaşılması hedeflenmiş, \%91.66'sına ulaşılmış, tüm çalışanlar araştırmaya dahil edilmiştir. Veri toplama aracı olarak, 6 bölümden oluşan 'Şanlıurfa'da Pestisit Satış Yerlerinde Çalışanların Sosyo-Demografik Özellikleri ve Semptom Tarama Soru Kâğıdı' Nörolojik Değerlendirme Ölçeği/ Q/ 16) ve Genel Sağlık Anketi (GSA/ 12) kullanılmıştır. Görüşme araçları yüzyüze görüşme ve gözlem tekniği kullanılarak doldurulmuştur. Bulgular: Araştırma 110 işyeri ve bu işyerlerinde çalışan

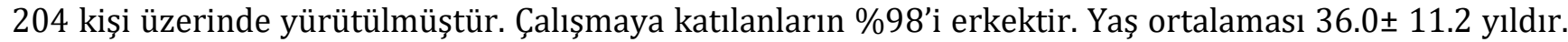
Çalışanların \%31.9'u Ziraat Mühendisi, Ziraat Teknisyeni ya da Meslek Yüksek Okulu (MYO) Bitki Koruma

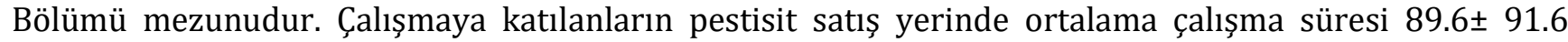
aydır. İşyeri ortam faktörleri incelendiğinde, Yönetmelik maddelerinin tümüne uygun satış yerine rastlanmamıştır. Çalışanların \%19.6'sı satış faaliyetlerine ek olarak, pestisit uygulama işlerinde de çalışmaktadır. Çalışanların \%27'si Q16 Nörolojik Değerlendirme Ölçeği'ne göre 6 ve üzerinde, \%29.9'u GSA/ 12 ölçeğine göre 1 ve üzerinde puan almıştır. Regresyon analizi sonucuna göre; nörolojik açıdan 6 ve üzerinde semptom varlığı ile pestisit uygulama ve pestisit satış yerinde çalışma süresi arasında, ruhsal semptom varlığı ile de öğrenim durumu arasındaki ilişki istatistiksel açıdan anlamlı bulunmuştur $(p<0.05)$. Sonuç: Bulgulara dayalı olarak, pestisit satışı ve uygulamasında çalışanların sağlık taramalarının yapılması ve güvenli pestisit uygulama davranışı kazandırılması ile işyeri ortam faktörlerinin kontrolü için eğitim ve denetim çalışmalarının yapılması önerilmektedir.

Anahtar Sözcükler: Bitki koruma ürünü satıcısı, nörolojik semptom, psikiyatrik semptom, bitki koruma ürünü uygulayıcısı

Yazının geliş tarihi: 27.03.2018

Yazının kabul tarihi: 13.09.2018

Sorumlu Yazar: Burcu Beyazgül, Harran Üniversitesi Tıp Fakültesi Halk Sağlığı ABD, Harran Üniversitesi Rektörlüğü, Osmanbey Yerleşkesi, Şanlıurfa-Mardin Karayolu Üzeri 18.Km, 63300 Şanlıurfa E-posta: brckara86@hotmail.com_Tel: 05072694236 


\title{
Neurological and psychiatric symptoms and related factors of plant protection products sales workers' in Şanlıurfa
}

\begin{abstract}
:
Aim: Mental and neurological disorders are considered in list of the most important public health problems in the world. In this study, it was aimed to search the compliance with the regulations of the selling places in Sanliurfa registered plant protection products (BKI), and to determine the neuropsychiatric symptoms and related factors of workers. Methot: This cross-sectional survey was approved by Harran University Medical Faculty Ethics Committee. The research population was composed of the pesticide salers that occurred in a total of 119 places, including the villages of central provinces based on the list obtained from Şanlıurfa Provincial Directorate of Food, Agriculture and Livestock in 2014. The screening method of the study aimed to reach all the places, $91.66 \%$ of work places that achieved in the field work where all workers participated the survey. 'Socio-Demographic Characteristics and Symptom Screening Questionnaire of Plant Protection Products Sales Workers' in Şanlıurfa' Neurological Symptom Scale (Q/ 16), and General Health Questionnaire 12 (GSA/12) were used for the data collection, including 6 dimentions. Questionnaire was applied by using face to face interview and observation techniques. Results: The study was conducted on 110 workplaces including 204 people. $98 \%$ of the study participants were male with mean age of $36.0 \pm 11.2$ years. $31.9 \%$ of the employees were Agricultural Engineers, Agricultural Technician or Plant Protection Department of Vocational High School (VHS). The mean working time at plant protection products sales was found to be as $89.6 \pm 91.6$ months. When the workplace environment factors were examined, it was not found the sales which fit all substance of the regulations. $19.6 \%$ of workers were applied pesticides in addition to sales activities. $27 \%$ of workers achieved 6 and higher scores based on the Q/ 16 Scale, while $29.9 \%$ of them had 1 and higher scores on the GSA/ 12 Scale levels. According to the result of regression analysis; neurologically, it was found that statistically significant relationship between 6 and higher score of the Q/ 16 and the presence of pesticide application and working time, the relationship between the presence of psychiatric symptoms and learning status was statistically significant $(\mathrm{p}<0.05)$. Conclusion: Based on the findings, it can be recommended that the health screening program of workers, the health education program for gaining the safe pesticide application behavior, and the training and audits programs for controlling environmental factors of workplaces should be conducted regularly.
\end{abstract}

Keywords: Plant protection product sailer, neurological symptom, psychiatric symptom, plant protection product applicator

\section{Giriş}

Pestisitler, çeşitli tarım ürünlerinin üretimi, taşınması ve depolanması sırasında ürün kaybına neden olabilecek zararlıların yok edilmesi, uzaklaştırılması, zararlarının azaltılması amacıyla kullanılan madde veya bileşikler olup, canlılar için zararlı etkileri olan, çevre kirliliğine neden olan maddelerdir. ${ }^{1}$ Pestisit, kimyasal bir madde, virüs ya da bakteri gibi biyolojik bir ajan, antimikrobik, dezenfektan ya da herhangi bir araç olabilmektedir. ${ }^{2}$

Pestisit, "Türk Gıda Kodeksi Pestisitlerin Maksimum Kalıntı Limitleri Yönetmeliği"nde, zirai mücadele uygulamalarında kullanılan her türlü kimyasal madde olarak tanımlanmaktadır. ${ }^{3}$ Bitki koruma ürünü ise; "Bitki Koruma Ürünleri Kontrol Yönetmeliği”nde, kullanıcıya farklı formlarda sunulan, bitki ve bitkisel ürünleri zararlı organizmalara karşı koruyan veya bu organizmaların etkilerini önleyen, bitki besleme amaçlı olanlar dışında bitki gelişimini etkileyen, koruyuculara ilişkin özel bir düzenleme kapsamında bulunmayan ancak bitkisel ürünleri koruyucu olarak kullanılan, bitki ve bitki kısımlarının istenmeyen gelişmelerini kontrol eden veya önleyen, istenmeyen bitkileri yok eden, bir veya daha fazla aktif maddeyi veya aktif madde, sinerji yaratan veya güvenilirliği artıran maddeler gibi 
bileşenleri içeren preparatlar olarak tanımlanmaktadır. ${ }^{4}$

Literatürde, tarımsal mücadelede kullanılan kimyasalların toplum sağlığı açısından risk faktörü olduğunu gösteren çok sayıda çalışma bulunmaktadır. $\mathrm{Bu}$ maddeler hedef olmayan organizmaya deri, göz, solunum ve sindirim yoluyla girmekte ve organizmada sinir sistemi başta olmak üzere tüm sistemleri olumsuz etkilemektedirler. Yapılan çalışmalar, organofosfatlı ürünlerin insanlarda zehirlenmelerin yanı sıra, özellikle düșük dozlarda uzun süre alındığında uzun dönemde çocukların sinir gelişimini olumsuz etkilediğini, dikkat eksikliği ve hiperaktivite bozukluğuna ve otizme neden olduğunu, çocukluk dönemi kanserlerinden lösemi, beyin tümörleri ve non-Hodgkin lenfoma için kesin risk faktörü olduğunu göstermiştir. Gebelik döneminde zararlı ot öldüren maddelere maruz kalan kadınların doğurduğu çocuklarda lösemi görülme riskinin diğerlerine göre iki kat olduğu, ileri yaşlarda parkinson, prostat, pankreas, böbrek ve meme kanseri riskini artırdığı saptanmıştır. Son yıllarda yapılan araștırmalar ise pestisitlerin tiroid bezi fonksiyonlarını bozduğunu, astımı artırdığını, solunum sistemini ve periferik sinir iletimini olumsuz etkilediğini göstermektedir. Ayrıca depresyon başta olmak üzere ruhsal bozukluklar ile menstrüel siklus düzensizlikleri için önemli kanıtlar elde edilmiştir. ${ }^{5-20}$

Literatürde insanların pestisitleri tanımalarının yüzyıllar öncesine dayandığı bildirilmektedir. Kutsal sayıların bazı tuzların, fethedilen yerlerin küllerinin nonselektive herbisit olarak Milattan önce (M.Ö) 1200 'lü yıllarda, kükürdün insektisit ve fungisit olarak M.Ö. 1000'li yıllarda, Hellebore (Helleborus Niger, Helleborus Orientalis ve Veratrum Album) adl bitkilerin fare, sıçan ve böceklerin kontrolü amacıyla M.Ö. 100'lü yıllarda kullanıldığı bilinmektedir. ${ }^{21}$

Türkiye'de tarımda pestisit sanayisi 1951 yılında kurulmaya başlamış, 1957 yılında yayınlanan 6968 sayılı "Zirai Mücadele ve Karantina Kanunu" ve 1958 yılından bu yana uygulamaya konulan yasal düzenlemeler, yerli ve ithal pestisit kalitelerinin uluslararası standartta olma zorunluluğunu getirmiştir. ${ }^{22} 2007$ yılında ise pestisitlerin depolanması, toptan veya perakende olarak satılması ve depolanması sırasında uyulması gereken esaslar yasal düzenlemelerle belirlenmiş ve ziraat mühendisi/ eczacl/ ziraat teknisyeni veya bitki sağlığı ile ilgili dersleri alarak mezun olmuş teknikerlerin sinavı geçmeleri halinde satış yapabilecekleri belirtilmiştir. ${ }^{23}$

Pestisit etkilenimi açısından, üretim fabrikalarında, depolamada, taşımada, satış yerlerinde, formülasyon fabrikalarında çalışanların, uygulayıcıların ve tarımda çalışanların öncelikli risk grubu olduğu bildirilmektedir. ${ }^{6}$ Hastalık ve erken ölümleri önlemede temel yaklaşım; riskin ortadan kaldırılması ya da etkilenimin kontrol altına alınmasıdır. Pestisitlerin insanlara ve diğer hedef olmayan canlılara etkisini en aza indirmek için, kişisel koruyucu donanıma erişim dahil, güvenli pestisit depolama ve uygulamanın sağlanması büyük önem taşımaktadır. ${ }^{24}$

Şanlıurfa ili, coğrafi bölge ayırımında Güneydoğu Anadolu Bölgesi'nin Orta Firat Bölümü'nde yer almaktadır. Kapladığı alan itibariyle, Güneydoğu Anadolu Bölgesi'nin en geniş ve Güneydoğu Anadolu Projesi'nin (GAP) merkezi konumundadır. Şanlıurfa, bölgedeki toplam tarım alanlarının \%36.2'sini, Türkiye'deki tarım alanlarının ise $\quad \% 4.2$ 'sini oluşturmaktadır. ${ }^{25}$ Araştırmalar, Şanlıurfa ilinde sulu tarıma geçiş, iklim ve diğer ekolojik özelliklerin hastalık, zararlı ve yabancl otlarm gelişmesine uygun olması nedeniyle, pestisit kullanımına ağırlı veren kimyasal mücadele yönteminin yaygın olduğunu, çiftçilerin kullandıkları pestisit tür ve miktarına uzmanlara başvurmadan, gelişigüzel uyguladıklarını ve satış yeri sayısının arttığını göstermektedir. ${ }^{26}$ Gerek çalışan sağlığ açısından pestisit satış yerlerinde çalışanların öncelikli risk gruplarından biri olması, gerekse toplumda güvenli pestisit uygulama davranışlarının yerleşmesinde doğru bilgiyle karşılaşma ve uygulamanın öğrenildiği yerlerin satış yerleri olması açısından, bu çalışmada Şanlıurfa il merkezine kayıtlı bitki koruma ürünü (BKÜ) satışı yapan işyerlerinin yasal 
düzenlemelere uygunluğunu, çalıșanların nöro-psikiyatrik semptomlarını ve bu semptomlarla ilişkili faktörleri belirlemek amaçlanmıştır.

\section{Yöntem}

Araştırma tarama niteliğinde yapılan kesitsel araştırmadır. $\mathrm{Bu}$ çalışma için, 23.05.2014 tarih ve 06 nolu oturum 22 sayılı karar ile Harran Üniversitesi Tıp Fakültesi etik kurul onayı alınmış, araştırma 2014- 2015 tarihleri arasinda yürütülmüştür. Araştırmanın giderleri Harran Üniversitesi Bilimsel Araştırma Fonu tarafından 1411 nolu 'Şanlıurfa'da Bitki Koruma Ürünü Satış Yerlerinde Çalışanlarda Nörolojik ve Psikiyatrik Semptomlar ve İlişkili Faktörler' adlı proje olarak karşılanmıştır.

Araștırmanın evrenini, 2014 yılında Şanlıurfa Gıda Tarım ve Hayvancilık İl Müdürlüğü'nden alınan listeye göre, il merkezi ve merkeze bağlı köylerde olmak üzere toplam 119 işyeri oluşturmuştur. Çalışma tarama çalışması niteliğinde olup, örnek seçilmemiş, listede bulunan tüm işyerlerine ulaşılması hedeflenmiş olup, işyerlerinin \%91.66'sına ulaşılmıştır. Beş satış yeri araştırmaya katılmayı reddetmiş, beş işyeri de kapanmıştır. İsim değişikliği yapanlar, adres değişikliği yapanlar ve farklı firma isimleri bildirdiği halde tek işyerinde ortak çalışan işyerleri de mevcuttur. Saha çalışmasının ilk aşaması, pestisit uygulamasının en yoğun olduğu Eylül 2014 tarihinde, işyerleri ziyaret edilerek yapılmış, ziyaretler sırasında ișyeri ortam faktörlerine ilişkin gözlem ve soru kağıtları doldurularak, psikiyatrik ve nörolojik semptomlar taranmıș ve enzimatik analizler için kan örnekleri alınmıştır. Ziyaret edilen tarihte işyerinde çalışan tüm kişiler araştırmaya dahil edilmiştir. Sonuç olarak çalışmada, 110 işyeri değerlendirmeye alınmış, işyerlerinde çalışan 204 kişiye ulaşılmıştır. İşyerlerinde çalışanlar içinde 40 kişi aktif olarak ilaç uygulama işlerinde de görev aldığı için ek olarak ayrı bir anketle de değerlendirilmiştir.

Veri toplama aracı olarak altı bölümden oluşan 'Şanlıurfa'da Pestisit Satış
Yerlerinde Çalıșanların Sosyo- Demografik Özellikleri ve Semptom Tarama Soru Kağıdı" kullanılmıștır. Birinci bölümünde katılımcının yaş, cinsiyet gibi demografik özelliklerini içeren 9 soru; ikinci bölümde katılımcının sağlık durumunun sorgulandığı 25 soru; üçüncü bölümde, "Bitki Koruma Ürünlerinin Toptan ve Perakende Satılması ile Depolanması Hakkında Yönetmelik" esas alınarak, işyerinin minimum özelliklerinin belirlendiği 22 soru; dördüncü bölümde ilaçlama işlerinde görev alan personele uygulanan ve güvenli pestisit uygulama davranışlarını içeren 13 soru; beşinci bölümde, 21 maddeden oluşan "Nörolojik Belirti Tarama Testi-Q/ 16 Ölçeği" altıncı bölümde ise, psikiyatrik semptomların sorgulandığı "Genel Sağlık Anketi 12 (GSA/ 12)" ölçeği yer almıștır. GSA/12 Goldberg tarafından geliştirilmiş ve Kılıç28 tarafından geçerlilik-güvenilirliği yapılmıştır. Depresyon, anksiyete, obsesyon olarak gözlenen davranış ve hipokondriazis olmak üzere dört alanda en az 15 gündür ya da en az iki haftadır devam eden semptomları içermektedir. Ölçek, her bir maddesi, "her zamankinden az"dan "her zamankinden fazla"ya uzanan 12 maddeden oluşmaktadır. GSA/ 12'nin puanlamasında bir yöntem; 0 ve 1'lerin 0 ; 2 ve 3 'lerin 1 şeklinde puanlanmasıdır. Buna göre alınacak en düşük puan 0 , en yüksek puan 12 'dir. Duyarlılığı $\quad 0.74$, özgüllüğü 0.84 'dür. Önerilen kesme noktası GSA toplam puanın 1 ya da 2 olmasıdır. Bu çalışmada kesme noktası 1 alınmıștır. ${ }^{27}$

Çalışanların değerlendirmesini yapabilmek için "Nörolojik Belirti Tarama Testi-Q/ 16 Ölçeği"den yararlanılmıştır. 16 nörolojik semptomun sorgulandığı ölçek, iki değerlendimeli olup, "evet" "hayır" şeklinde kodlanmıştır. Ölçeğin puanları önerildiği üzere $0-1$ olarak kodlanmıştır. Önerilen kesme noktası Q 16 toplam puanın 6-7 olmasıdır. Bu çalışmada kesme puanı diğer çalışmalara benzer şekilde 6 olarak alınmıştır. ${ }^{28}$

$$
\text { İşyeri ziyareti esnasında, }
$$
işyerlerinde çalışan ve çalışmayı katılmayı kabul eden herkesten kan alınması planlanmış olup, 13 kişi kan vermeyi reddettiği için, 191 kişiden kan örneği 
alınmıştır. İşyeri ziyareti sırasında asetilkolinesteraz çalışılması için katılımcılardan kan alınmış, alınan kanlar soğuk zincir şartları sağlanarak taşınmış, Harran Üniversitesi biyokimya laboratuarında santrifüj edilmiş, daha sonra da plazmada asetilkolinesteraz düzeyi ölçümü enzimatik yöntemle kit kullanılarak yapılmıştır. Ayrıca, EMG için riskli olduğu düşünülen her katılımcıdan ikinci kez kan alınarak, glikoz, üre, kreatin, HbA1c çalışılmış, böylece polinöropatiye sebep olabilecek bazı faktörler (diyabet, böbrek ve karaciğer patolojileri) dışlanmaya çalışılmıştır.

Nörolojik tarama testi sonucu risk tespit edilen 55 kişi (Q16 Testi 6 puan ve üzeri olanlar ya da iğnelenme, karıncalanma gibi nöropati semptomları gösterenler) ve asetikolinesteraz enzimi merkez laboratuvara göre düşük tespit edilen 6 kişi nöropati gelişimi açısından risk altında kabul edilerek 61 kişiye EMG uygulanması planlanmıştır. 16 katılımcı EMG randevusuna gelmeyi reddetmiş, riskli görülenlerin \%73.8'ine ulaşılarak, Harran Üniversitesi Tıp Fakültesi Nöroloji Polikliniği'nde EMG uygulanmış ve değerlendirilmiştir. EMG için riskli olduğu düşünülen her katılımcıdan ikinci kez kan alınarak, glikoz, üre, kreatin, HbA1c çalışılmıştır.

Araştırmada SPSS 11.5 istatistik paket programı kullanılarak istatistiksel analizler yapılmıştır. Tanımlayıcı istatistikler, tekli analizlerde ki-kare testi ve regresyon analizi yapılmıştır. Regresyon modeline alınan öğrenim durumu değişkeni fark yaratan grup dikkate alınarak, dikotom hale çevrilerek regresyon modeline alınmıştır. Lojistik regresyon analizinde enter modeli kullanılmıştır. Anlamlılık düzeyi $p<0.05$ kabul edilmiştir.

Nörolojik ve psikiyatrik açıdan tekli analizlerde anlamlı ilişki bulunan her bir bağımsız değişkenin bağımlı değişken üzerindeki etkisini ve ilişkinin yönünü belirlemek, ayrıca karıştırıcı faktörleri kontrol etmek amaciyla regresyon analizi yapılmış olup, Tablo 8'de sonuçları gösterilmiştir. Nörolojik semptom açısından, doktor tanılı hastalığı olan, pestisit uygulama işlerinde çalışan ve işyerlerinde 60 ay ve üzerinde çalışanlar regresyon modeline alınmıştır. Psikiyatrik semptom açısından, işyerinde lavabo bulunan, lavaboda sabun bulunan, işyerlerinde 60 ay ve üzerinde çalışan, lise ve üzeri eğitimi olanlar regresyon modeline alınmıştır.

\section{Bulgular}

Araștırma 110 işyeri ve bu işyerlerinde çalışan 204 kişi üzerinde yürütülmüştür. Tablo 1'de görüldüğü üzere, çalışanların \%98'i erkek, \%74.5'i evli olup, yaş ortalaması $36.0 \pm 11.2$ yıldır (Kadınların $26.0 \pm 0.8$, erkeklerin $36.2 \pm 11.2$ yll). Çalışanların öğrenim durumu incelendiğinde; \%21.6'sı ilköğretim 1. kademe ve altı, \%21.6'sı ilköğretim 2. kademe ve üzeri, \%17.2'si lise ve dengi okul, \%39.2'si de üniversite ve üzeri öğrenim görmüşlerdir. Çalışanların \%31.9'u Ziraat Mühendisi, Ziraat Teknisyeni ya da Meslek Yüksek Okulu (MYO) Bitki Koruma Bölümü mezunudur. Çalışanların pestisit satış yerinde çalışma süresi üç ay ile 600 ay

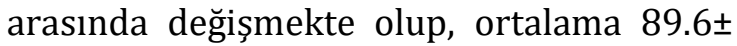
91.6 (minimum:3, maksimum: 600 ay) aydir.

Çalışanların sağlık/ hastalık durumları ve bazı alışkanlıklarının dağılımı Tablo 2'de gösterilmiștir. Tabloda izlendiği gibi, çalışanların \%34.8'i sağlıklarını kötü ya da orta olarak değerlendirmiștir. Çalışanların \%49.5'i halen sigara içerken, \%8.8'i ise halen alkol kullanmakta olduğunu bildirmiştir. Çalışanların \%31.4'ü doktor tarafından tanısı konulmuş hastalıkları olduğunu, $\% 25.5^{\prime} \mathrm{i}$ ise sürekli ilaç kullandığını bildirmiştir. Çalışanların \%10.3'ü satış yerinde çalışmaya başlamadan önce işe giriş muayenesi yaptırdığını, \%6.4'ü altı ayda bir sağlık muayenesinden geçtiklerini belirtmiştir.

Çalışma kapsamında 110 işyeri ziyaret edilmiş olup, 5 işyeri büro şeklindedir ve işyerinde ilaç bulunmamaktadır. Geriye kalan işyerlerinin \%85.7'si bayi- perakendeci, \%7.6's toptancl, \%6.7'si ise depo olarak faaliyet görmektedir. 
Tablo 1. Pestisit satış yerlerinde çalışanların sosyo-demografik özellikleri

\begin{tabular}{|c|c|c|}
\hline Temel Özellikler & Sayı & Yüzde \\
\hline \multicolumn{3}{|l|}{ Cinsiyet } \\
\hline Kadın & 4 & 2.0 \\
\hline Erkek & 200 & 98.0 \\
\hline \multicolumn{3}{|l|}{ Yaş grupları } \\
\hline 29 yaş ve altı & 58 & 28.4 \\
\hline 30-45 yaş arası & 113 & 55.4 \\
\hline 46 yaş ve üzeri & 33 & 16.2 \\
\hline \multicolumn{3}{|l|}{ Medeni durum } \\
\hline Evli & 152 & 74.5 \\
\hline Evlenmemiş & 52 & 25.5 \\
\hline \multicolumn{3}{|l|}{ Öğrenim durumu } \\
\hline $\begin{array}{l}\text { İlköğretim 1. kademe ve } \\
\text { altı }\end{array}$ & 44 & 21.6 \\
\hline $\begin{array}{l}\text { İlköğretim 2. kademe ve } \\
\text { üzeri }\end{array}$ & 44 & 21.6 \\
\hline Lise ve dengi okul & 35 & 17.2 \\
\hline Üniversite ve üzeri & 81 & 39.2 \\
\hline \multicolumn{3}{|l|}{ Mesleği } \\
\hline $\begin{array}{l}\text { Ziraat Mühendisi, Ziraat } \\
\text { Teknisyeni ya da MYO } \\
\text { Bitki Koruma Bölümü } \\
\text { mezunu }\end{array}$ & 65 & 31.9 \\
\hline Diğer & 139 & 68.1 \\
\hline \multicolumn{3}{|l|}{ İşyerinde çalışma süresi } \\
\hline 59 ay ve altı & 96 & 47.1 \\
\hline 60 ay ve üzeri & 108 & 52.9 \\
\hline Toplam & 204 & 100.0 \\
\hline
\end{tabular}

Tablo 3'te satış yerlerinin Yönetmelik maddelerine uygunluk durumu verilmiştir. Tabloda görüldüğü gibi; yasal olarak uygun olmamasına rağmen işyerlerinin \%96.2'sinin etrafında ev ve işyeri bulunmaktadır. İşyerlerinin \%85.7'sinde çok zehirli raf ve bölmelerde "Çok Zehirli Bitki Koruma Ürünleri" ifadesi, \%80.0'ında ilk bakışta görülebilecek ve okunabilecek şekilde "bitki koruma ürünleri insan, hayvan ve çevre için zehirli ve tehlikelidir" ifadesi bulunmamaktadır. Satıș yerlerinin \%88.6'sında ilaçlamada kullanılan koruyucu araç ve gereç satılmamaktadır. İşyerlerinin \%20.9'unda Gıda, Tarım ve Hayvancılık Bakanlığı tarafından satışı yasaklanmış bazı pestisitlerin satışının yapıldığı tespit edilmiştir. Yönetmelik maddelerinin tümüne uygun satış yerine rastlanmamıştır.

Tablo 2. Pestisit satış yerlerinde çalışanların genel sağlık durumu

\begin{tabular}{|c|c|c|}
\hline Temel Özellikler & Sayl & Yüzde \\
\hline \multicolumn{3}{|l|}{ Sağlık algısı } \\
\hline Kötü- orta & 71 & 34.8 \\
\hline İyi & 120 & 58.8 \\
\hline Çok iyi & 13 & 6.4 \\
\hline \multicolumn{3}{|c|}{ Sigara içme durumu } \\
\hline Hiç içmemiş & 66 & 32.4 \\
\hline Bırakmış & 37 & 18.1 \\
\hline Halen içiyor & 101 & 49.5 \\
\hline \multicolumn{3}{|c|}{ Alkol kullanma durumu } \\
\hline Hiç İçmemiş & 172 & 84.3 \\
\hline Bırakmış & 14 & 6.9 \\
\hline Halen İçiyor & 18 & 8.8 \\
\hline \multicolumn{3}{|c|}{ Doktor tarafından tanı konulmuş hastalık } \\
\hline Var & 64 & 31.4 \\
\hline Yok & 140 & 68.6 \\
\hline \multicolumn{3}{|c|}{ Sürekli kullanılan ilaç } \\
\hline Var & 52 & 25.5 \\
\hline Yok & 152 & 74.5 \\
\hline \multicolumn{3}{|c|}{ İşe giriş muayenesi } \\
\hline Evet & 21 & 10.3 \\
\hline Hayır & 183 & 89.7 \\
\hline Toplam & 204 & 100.0 \\
\hline
\end{tabular}

Çalışanların $\quad \% 19.6$ 'sı $\quad(40 \quad$ kişi $)$ işyerindeki satış faaliyetlerine ek olarak, aynı zamanda ilaçlama işlerinde de görev aldıklarını bildirmişlerdir. Uygulayıcıların \%27.5'i Ziraat Mühendisi, Ziraat Teknisyeni ya da MYO Bitki Koruma Bölümü mezunudur. İlaçlamada görev alan çalışanlara, güvenli pestisit uygulama davranışlarını içeren sorular yöneltilmiştir. Tablo 4'te çalışanların BKÜ seçimi ve 
uygulama öncesi hazırlık davranışlarına ait bazı parametreler gösterilmiştir. İlaçlama işlerinde çalışanların \%42.5'i ilaçlama ile ilgili eğitim almıștır. Uygulayıcıların \%90’ı ilaçlamada kullanılacak ilacın seçimin işyerlerindeki yetkili kişinin yaptığını, \%92.5'i imalatçı firmanın belirttiği ilaçlama dozuna uyduğunu, \%57.5'i pestisitlerin özel kaplarda saklandığını, \%90'ı pestisit kaplarının/ konteynırların mühürlü olduğunu ifade etmiştir.

Çalışanların Q16 Nörolojik Değerlendirme Ölçeği'ne göre ortalama semptom sayısı $3.3 \pm 3.0$ (en düșük 0 , en yüksek 15)'dür. Satış işlerine ek olarak, ilaçlama işlerinde de görev alanların ortalama semptom sayısı $4.3 \pm 3.7$ olup, bu farklılık istatistiksel açıdan anlamlıdır $(\mathrm{p}<0.05)$. Satış yerinde çalışma süresi 60 ay ve üzeri olanlarda ortalama semptom sayısı $3.7 \pm 3.3$ olup, bu farklılık istatistiksel açıdan anlamlıdır $(\mathrm{p}<0.05)$. Çalışanların GSA/ 12 Ölçeği'ne göre ortalama semptom sayısı $0.7 \pm 1.5$ (en düşük: 0, en yüksek: 10)'dür. Satış işlerine ek olarak, ilaçlama işlerinde de görev alanların ortalama semptom sayısı $0.9 \pm 1.9$, satış yerinde çalışma süresi 60 ay ve üzeri olanların $0.9 \pm 1.7$ 'dür ve bu farklılık istatistiksel açıdan anlamlı değildir ( $p>0.05)$.

Tablo 3. Pestisit satış yerlerinin yönetmelik açısından uygunluk durumu

\begin{tabular}{|c|c|c|c|c|}
\hline \multirow[t]{2}{*}{ Satış Yerlerinin Özellikleri } & \multicolumn{2}{|c|}{ Uygun Olanlar } & \multicolumn{2}{|c|}{ Uygun Olmayanlar } \\
\hline & Sayl & Yüzde & Sayı & Yüzde \\
\hline Satış yerinin etrafında ev ve işyeri bulunma durumu & 4 & 3.8 & 101 & 96.2 \\
\hline $\begin{array}{l}\text { Çok zehirli raf ve bölmelerde "çok zehirli bitki koruma } \\
\text { ürünleri" ifadesi bulunma durumu }\end{array}$ & 15 & 14.3 & 90 & 85.7 \\
\hline İlaçlamada kullanılan koruyucu ekipman satışı & 12 & 11.4 & 93 & 88.6 \\
\hline $\begin{array}{l}\text { Satış yerinde ilk bakışta görülebilecek ve okunabilecek } \\
\text { șekilde "bitki koruma ürünleri insan, hayvan ve çevre } \\
\text { için zehirli ve tehlikelidir" ifadesi bulunma durumu }\end{array}$ & 21 & 20.0 & 84 & 80.0 \\
\hline Yangın söndürme cihazı bulunma durumu & 51 & 48.6 & 54 & 51.4 \\
\hline $\begin{array}{l}\text { Zararlı kokuların giderilmesi için havalandırma düzeni } \\
\text { bulunma durumu }\end{array}$ & 32 & 30.5 & 73 & 69.5 \\
\hline $\begin{array}{l}\text { Bitki koruma ürünlerinin olumsuz etkilerine maruz } \\
\text { kalınmaması için muhafazalı oda bulunma durumu }\end{array}$ & 74 & 70.5 & 31 & 29.5 \\
\hline $\begin{array}{l}\text { Çok zehirli bitki koruma ürünleri için ayrı raf ve bölme } \\
\text { bulunma durumu }\end{array}$ & 32 & 30.5 & 73 & 69.5 \\
\hline Satış yerinde açıkta satılan ürün bulunma durumu & 93 & 88.6 & 12 & 11.4 \\
\hline $\begin{array}{l}\text { Satış yerinde aynı ortamda insan ve hayvan gıdalarının } \\
\text { satıșı }\end{array}$ & 102 & 97.1 & 3 & 2.9 \\
\hline Lavaboda sabun bulunma durumu & 84 & 80.0 & 21 & 20.0 \\
\hline El ve yüz yıkanabilecek lavabo bulunma durumu & 91 & 86.7 & 14 & 13.3 \\
\hline Etiketsiz bitki koruma ürünü satışı & 98 & 93.3 & 7 & 6.7 \\
\hline Ruhsatsız ürün satışı & 102 & 97.1 & 3 & 2.9 \\
\hline Kullanma süresi geçmiş bitki koruma ürünü satışı & 78 & 74.3 & 27 & 25.7 \\
\hline Atık suların giderilmesi için kanalizasyon tertibatı & 58 & 55.2 & 47 & 44.8 \\
\hline Yasaklanmıș ürün satıșı & 83 & 79.1 & 22 & 20.9 \\
\hline
\end{tabular}


Tablo 5'te seçilen sosyo-demografik değişkenlere göre nörolojik ve psikiyatrik semptom varlığı gösterilmiştir. Nörolojik açıdan 6 ve üzerinde semptom varlığı ile cinsiyet, yaş, öğrenim durumu ve medeni durum arasında istatistiksel açıdan anlamlı bir ilişki bulunmamıştır ( $p>0.05)$. İşyerinde çalışma süresi 60 ay ve üzeri olanlarda ve pestisit uygulama işlerinde aktif çalışanlarda nörolojik açıdan 6 ve üzerinde semptom varlığı daha fazla görülmektedir $(\mathrm{p}<0.05)$. Cinsiyet, yaş, medeni durum ve pestisit uygulama durumu ile 1 ve üzerinde psikiyatrik semptom gösterip göstermeme arasında istatistiksel açıdan anlamlı bir ilişki bulunmamıştır ( $p>0.05$ ). Lise ve üzeri öğrenim görenlerde ve işyerinde çalışma süresi 60 ay ve üzeri olanlarda 1 ve üzerinde psikiyatrik semptom görülme sıklı̆̆ daha fazladır $(\mathrm{p}<0.05)$.

Nörolojik ve psikiyatrik semptom durumu sağlık algısı, hastalık durumları ve alışkanlıkları açısından incelenmiş olup, sonuçlar Tablo 6'da verilmiştir. Nörolojik açıdan altı ve üzerinde semptom varlığı ile sağlık algısı, sigara içme durumu, alkol kullanma durumu, sürekli ilaç kullanma durumu arasında istatistiksel açıdan anlamlı bir ilişki bulunmamıştır ( $\mathrm{p}>0.05)$. Doktor tarafından tanı konmuş hastalığı olanlarda altı ve üzerinde nörolojik semptom sıklığı anlamlı olarak daha yüksektir $(\mathrm{p}<0.05)$. Çalışanların bir ve üzerinde psikiyatrik semptom gösterip göstermemesi ile sağlık algısı, sigara içme durumu, alkol kullanma durumu, doktor tarafından tanı konmuş hastalık öyküsü, sürekli kullandığı ilaç olup olmaması durumu arasında istatistiksel açıdan anlamlı bir ilişki bulunmamıştır ( $p>0.05)$.

Çalışanların nörolojik ve psikiyatrik semptom durumu işyeri ortam faktörleri açısından incelenmiş olup, sonuçlar Tablo 7'de verilmiştir. Nörolojik açıdan altı ve üzerinde semptom varlığı ile işyeri ortam faktörleri arasında istatistiksel açıdan anlamlı bir ilişki bulunmamıştır ( $p>0.05)$. El ve yüz yıkanabilecek lavabo ve lavaboda sabun bulunanlarda bir ve üzerinde psikiyatrik semptom görülme sıklığ anlamlı olarak daha yüksektir $(\mathrm{p}<0.05)$.
Tablo 4. Pestisit uygulamada aktif çalışanların davranışları

\begin{tabular}{lcc}
\hline Davranışlar & Sayı & Yüzde \\
\hline İlaçlama eğitimi alma durumu & & \\
Alan & 17 & 42.5 \\
Almayan & 23 & 57.5 \\
\cline { 2 - 3 } İlaç seçimini yapan kişi & & \\
İşyerimizdeki yetkili kişi & 36 & 90.0 \\
seçer & & \\
Diğer & 4 & 10.0 \\
\hline İmalatçı firmanın belirttiği doza uyma durumu \\
Uyan & 37 & 92.5 \\
Uymayan & 3 & 7.5 \\
\hline Pestisitlerin özel kaplarda olma durumu \\
Evet & 23 & 57.5 \\
Hayır & 17 & 42.5 \\
\hline Pestisit kapları / konteynırlarının mühürlü \\
olma durumu & & \\
Evet & 36 & 90.0 \\
Hayır & 4 & 10.0 \\
\hline Toplam & 40 & 100.0 \\
\hline
\end{tabular}

Nörolojik açıdan altı ve üzerinde semptom varlığ ile pestisit uygulama ve pestisit satış yerinde çalışma süresi arasındaki ilişki istatistiksel açıdan anlamlı bulunmuştur $(\mathrm{p}<0.05)$. Nörolojik semptom varlığını pestisit uygulama 2.3 kat (GA \%95: 1.1- 4.9), 60 ay ve üzerinde satış yerinde çalışma 2.5 kat (GA \%95: 1.2- 4.8) artırmaktadır. GSA/ 12'ye göre bir ve üzerinde psikiyatrik semptom varlığı ile öğrenim durumu arasındaki ilişki istatistiksel açıdan anlamlı bulunmuştur $(\mathrm{p}<0.05)$. Lise ve üzerinde öğrenimi olanlarda 2.3 kat (GA\%95: 1.2- 4.5) daha fazla psikiyatrik semptom görülmüştür.

EMG için riskli olduğu düşünülen çalışanlardan, üniversite hastanesine EMG randevusuna geldiklerinde ikinci kez kan alınarak, glikoz, üre, kreatin, HbA1c çalışılmış, böylece polinöropatiye sebep olabilecek bazı faktörler dişlanmaya çalışılmıştır. 
Çalışanların kreatin düzeyi ortalaması $0.8 \pm 0.1 \mathrm{mg} / \mathrm{dL}$ olup, normal değer aralığındadır. Çalışanların glikoz ölçüm düzeyi ortalaması $102 \pm 39.2 \mathrm{mg} / \mathrm{dL}$ olup, ölçülen kanlar açlık kan glikozu değil, rastgele bir zamanda ölçülen kan glikozudur. Buna göre rastgele kan glikoz değeri maksimum düzeyi olan $200 \mathrm{mg} / \mathrm{dL}$ 'nin üstünde olan bir tek ölçüm mevcut olup, $314 \mathrm{mg} / \mathrm{dL}$ olarak ölçülmüştür. Çalışanların hbA1c düzeyi ortalaması \%5.7 \pm 0.7'dir. HbA1c düzeyi maksimum düzeyi $\% 6.5$ olup, bu değerin üzerinde olan 3 ölçüm mevcuttur (\%6.7, \%7.0 ve \%9.2). Asetilkolinesteraz enzim düzeyi düşük olanların ise, hepsinin üre, kreatin ve HbA1c düzeyleri normal sınırlardadır.

Çalışanların pestisitlere bağlı polinöropati açısından incelenmesi amacıyla, nörolojik tarama testi sonucu risk tespit edilen 55 kişi (Q 16 Testi altı puan ve üzeri olanlar ya da iğnelenme, karıncalanma gibi nöropati semptomları gösterenler) ve asetikolinesteraz enzimi merkez laboratuvara göre düşük tespit edilen altı kişi nöropati gelişimi açısından risk altında kabul edilerek 61 kişiye EMG uygulanması (Polinöropati protokolü) planlanmıştır. 16 katılımcı EMG randevusuna gelmeyi reddetmiş, riskli görülenlerin \%73.8'ine ulaşılarak, EMG uygulanmış ve değerlendirilmiştir. EMG sonuçları normal olarak raporlanmıştır.

\section{Tartışma}

$\mathrm{Bu}$ araştırma Şanlıurfa ilinde sulu tarıma geçişle beraber, gerek toplum sağlığının gerekse çalışan sağlığının korunması açısından önemli olan pestisit satış yerlerinin yasal düzenlemelere uygunluğunu, çalışanlarda nörolojik ve psikiyatrik semptom sıklığını ve ilişkili faktörleri belirlemek amacıyla yapılmıştır.

Gerek çalışma hayatı, gerekse pestisitle ilgili uygulama ve protokoller yasalarla düzenlenmiştir. 10.03.2011 tarihli ve 27870 sayll resmi gazetede "Bitki Koruma Ürünlerinin Toptan ve Perakende Satılması ile Depolanması Hakkında Yönetmelik" yayınlanmış olup; Bakanlıkça onaylı bitki koruma ürünlerinin toptan veya perakende olarak satılması ve depolanması ile bu ürünleri toptan ve perakende satacak ve depolayacakların uyması gereken esasların belirlenmesi amaçlanmaktadır. Yönetmeliğin 5. maddesinde bitki koruma ürünlerinin toptan ve perakende satışlarının, bitki koruma ürünleri bayi/ toptancı izin belgesi sahibi olan kişiler tarafından yapılması gerektiği belirtilmekte, 6 . maddesinde de bayi/ toptancl izin belgesi alabilecek kişilerin, ziraat mühendisi veya eczacı veya ziraat teknisyeni veya bitki sağlığı ile ilgili dersleri alarak mezun olmuş tekniker olması gerektiği ifade edilmektedir. ${ }^{29}$ Çalışmamızda, işyerinin ziyaret edildiği saatte satış yapanların yaklaşık \%39'u ziraat mühendisi, ziraat teknisyeni ya da MYO Bitki Koruma Bölümü mezunudur. Kara ve Şimșek'in ${ }^{30}$ 2013 yılında Güneydoğu Anadolu Bölgesi'ni temsil eden örnek üzerinde (Adıyaman, Batman, Diyarbakır, Gaziantep, Kilis, Mardin, Şanlıurfa, Siirt ve Şırnak) yaptıkları araştırmada, benzer şekilde pestisit satış yerlerinde çalışanların $\% 36$ 'sı ziraat mühendisi, \%10.9'u ziraat teknisyeni, \%1.6'sı MYO Bitki Koruma Bölümü mezunu olmak üzere \%48.6'sı mesleki eğitim almıştır. Bu iki çalışmadaki veriler benzerlik göstermektedir. Çalışmamıza katılanların tamamına yakını erkektir. Kara ve Şimşek'in ${ }^{30}$ yaptıkları çalışmada ise, katılımcıların \%96.9'unun erkek olduğu belirlenmiştir. Bu iki çalışmadaki veriler benzerlik göstermektedir Her iki çalışmada da erkek oranının yüksek olmasının nedeni, kadının eğitim düzeyinin düşük olması ve özel sektörde kendi işini kurma davranışının bölgesel fark göstermesiyle açıklanabilir. ${ }^{31}$ 
Tablo 5. Sosyo-demografik değişkenlere göre pestisit satış yerlerinde çalışanlarda nörolojik ve psikiyatrik semptom durumu

\begin{tabular}{|c|c|c|c|c|c|c|c|c|}
\hline \multirow[b]{3}{*}{ Değişkenler } & \multicolumn{4}{|c|}{ Nörolojik Semptom (Q/ 16) } & \multicolumn{4}{|c|}{ Psikiyatrik Semptom (GSA/ 12) } \\
\hline & \multicolumn{2}{|c|}{6 ve üzeri } & \multicolumn{2}{|c|}{5 ve altı } & \multicolumn{2}{|c|}{ Semptom var } & \multicolumn{2}{|c|}{ Semptom yok } \\
\hline & Sayı & Yüzde & Sayı & Yüzde & Sayl & Yüzde & Sayı & Yüzde \\
\hline \multicolumn{9}{|l|}{ Cinsiyet } \\
\hline Kadın & 2 & 50.0 & 2 & 50.0 & 0 & 0.0 & 4 & 100.0 \\
\hline \multirow[t]{2}{*}{ Erkek } & 53 & 26.5 & 147 & 73.5 & 61 & 30.5 & 139 & 69.5 \\
\hline & \multicolumn{2}{|c|}{ Fisher Exact Test } & \multicolumn{2}{|c|}{$\mathrm{P}=0.29$} & \multicolumn{2}{|c|}{$\mathrm{X}^{2}=1.7$} & \multicolumn{2}{|c|}{$\mathrm{P}=0.31$} \\
\hline \multicolumn{9}{|l|}{ Yaş grupları } \\
\hline 29 yaş ve altı & 16 & 27.6 & 42 & 72.4 & 17 & 29.3 & 41 & 70.7 \\
\hline 30-45 yaş arası & 30 & 26.5 & 83 & 73.5 & 33 & 29.2 & 80 & 70.8 \\
\hline \multirow[t]{2}{*}{46 yaş ve üzeri } & 9 & 27.3 & 24 & 72.7 & 11 & 33.3 & 22 & 66.7 \\
\hline & \multicolumn{2}{|c|}{$X^{2}=0.0$} & \multicolumn{2}{|c|}{$\mathrm{P}=0.98$} & \multicolumn{2}{|c|}{$\mathrm{X}^{2}=0.2$} & \multicolumn{2}{|c|}{$\mathrm{P}=0.89$} \\
\hline \multicolumn{9}{|l|}{ Öğrenim durumu } \\
\hline İlköğretim 1. & 7 & 15.9 & 37 & 84.1 & 5 & 11.4 & 39 & 88.6 \\
\hline \multicolumn{9}{|l|}{ kademe ve altı } \\
\hline İlköğretim 2. & 13 & 29.5 & 31 & 70.5 & 12 & 27.3 & 32 & 72.7 \\
\hline \multicolumn{9}{|l|}{ kademe ve üzeri } \\
\hline Lise ve dengi okul & 11 & 31.4 & 24 & 68.6 & 15 & 42.9 & 20 & 57.1 \\
\hline \multirow[t]{2}{*}{ Üniversite ve üzeri } & 24 & 29.6 & 57 & 70.4 & 29 & 35.8 & 52 & 64.2 \\
\hline & \multicolumn{2}{|c|}{$X^{2}=3.5$} & \multicolumn{2}{|c|}{$\mathrm{P}=0.15$} & \multicolumn{2}{|c|}{$X^{2}=11.5$} & \multicolumn{2}{|c|}{$P=0.00$} \\
\hline \multicolumn{9}{|l|}{ Medeni durum } \\
\hline Evli & 41 & 27.0 & 111 & 73.0 & 44 & 28.9 & 108 & 71.1 \\
\hline \multirow[t]{2}{*}{ Bekar } & 14 & 26.9 & 38 & 73.1 & 17 & 32.7 & 35 & 67.3 \\
\hline & \multicolumn{2}{|c|}{$X^{2}=0.0$} & \multicolumn{2}{|c|}{$\mathrm{P}=1.00$} & \multicolumn{2}{|c|}{$\mathrm{X}^{2}=0.2$} & \multicolumn{2}{|c|}{$\mathrm{P}=0.60$} \\
\hline
\end{tabular}

\begin{tabular}{|c|c|c|c|c|c|c|c|c|}
\hline \multicolumn{9}{|c|}{ İşyerinde çalıșma süresi } \\
\hline 59 ay ve altı & 16 & 16.7 & 80 & 83.3 & 22 & 22.9 & 74 & 77.1 \\
\hline \multirow[t]{2}{*}{60 ay ve üzeri } & 39 & 36.1 & 69 & 63.9 & 39 & 36.1 & 69 & 63.9 \\
\hline & \multicolumn{2}{|c|}{$X^{2}=9.7$} & \multicolumn{2}{|c|}{$P=0.00$} & \multicolumn{2}{|c|}{$\mathrm{X}^{2}=4.2$} & \multicolumn{2}{|c|}{$P=0.04$} \\
\hline \multicolumn{9}{|c|}{ Pestisit uygulama durumu } \\
\hline Evet & 17 & 42.5 & 23 & 57.5 & 15 & 37.5 & 25 & 62.5 \\
\hline \multirow[t]{2}{*}{ Hayır } & 38 & 23.2 & 126 & 76.8 & 46 & 28.0 & 118 & 72.0 \\
\hline & \multicolumn{2}{|c|}{$X^{2}=6.1$} & \multicolumn{2}{|c|}{$P=0.01$} & \multicolumn{2}{|c|}{$X^{2}=1.4$} & \multicolumn{2}{|c|}{$\mathrm{P}=0.24$} \\
\hline Toplam & 55 & 27.0 & 149 & 73.4 & 61 & 29.9 & 143 & 70.1 \\
\hline
\end{tabular}


Tablo 6. Pestisit satış yerlerinde çalışanların sağlık algısı, hastalık varlığı ve alışkanlıklarına göre nörolojik ve psikiyatrik semptom durumu

\begin{tabular}{|c|c|c|c|c|c|c|c|c|}
\hline \multirow{3}{*}{ Değişkenler } & \multicolumn{4}{|c|}{ Nörolojik Semptom (Q/16) } & \multicolumn{4}{|c|}{ Psikiyatrik Semptom (GSA/12) } \\
\hline & \multicolumn{2}{|c|}{6 ve üzeri } & \multicolumn{2}{|c|}{5 ve altı } & \multicolumn{2}{|c|}{ Semptom var } & \multicolumn{2}{|c|}{ Semptom yok } \\
\hline & Sayı & Yüzde & Sayl & Yüzde & Sayı & Yüzde & Sayı & Yüzde \\
\hline \multicolumn{9}{|l|}{ Sağlık algısı } \\
\hline Kötü - orta & 26 & 36.6 & 45 & 63.4 & 22 & 31.0 & 49 & 69.0 \\
\hline İyi & 27 & 22.5 & 93 & 77.5 & 34 & 28.3 & 86 & 71.7 \\
\hline \multirow[t]{2}{*}{ Çok iyi } & 2 & 15.4 & 11 & 84.6 & 5 & 38.5 & 8 & 61.5 \\
\hline & \multicolumn{2}{|c|}{$X^{2}=5.5$} & \multicolumn{2}{|c|}{$\mathrm{P}=0.06$} & \multicolumn{2}{|c|}{$X^{2}=0.6$} & \multicolumn{2}{|c|}{$\mathrm{P}=0.72$} \\
\hline \multicolumn{9}{|c|}{ Sigara içme durumu } \\
\hline Hiç içmemiş & 15 & 22.7 & 51 & 77.3 & 18 & 24.2 & 50 & 75.8 \\
\hline Bırakmış & 9 & 24.3 & 28 & 75.7 & 7 & 18.9 & 30 & 81.1 \\
\hline \multirow[t]{2}{*}{ Halen içiyor } & 31 & 30.7 & 70 & 69.3 & 38 & 37.6 & 63 & 62.4 \\
\hline & \multicolumn{2}{|c|}{$X^{2}=1.4$} & \multicolumn{2}{|c|}{$\mathrm{P}=0.48$} & \multicolumn{2}{|c|}{$X^{2}=6.0$} & \multicolumn{2}{|c|}{$\mathrm{P}=0.05$} \\
\hline \multicolumn{9}{|c|}{ Alkol kullanma durumu } \\
\hline Hiç içmemiş & 45 & 26.2 & 127 & 73.8 & 52 & 30.2 & 120 & 69.8 \\
\hline Bırakmış & 3 & 21.4 & 11 & 78.6 & 2 & 14.3 & 12 & 85.7 \\
\hline \multirow[t]{2}{*}{ Halen içiyor } & 7 & 38.9 & 11 & 61.1 & 7 & 38.9 & 11 & 61.1 \\
\hline & \multicolumn{2}{|c|}{ Fisher Exact Test } & \multicolumn{2}{|c|}{$\mathrm{P}=0.35$} & \multicolumn{2}{|c|}{$\mathrm{X}^{2}=2.3$} & \multicolumn{2}{|c|}{$\mathrm{P}=0.31$} \\
\hline \multicolumn{9}{|c|}{ Doktor tarafından tanı konulmuş hastalık varlığı } \\
\hline Var & 24 & 37.5 & 40 & 62.5 & 23 & 35.9 & 41 & 64.1 \\
\hline \multirow[t]{2}{*}{ Yok } & 31 & 22.1 & 109 & 77.9 & 38 & 27.1 & 102 & 72.9 \\
\hline & \multicolumn{2}{|c|}{$\mathrm{X}^{2}=5.3$} & \multicolumn{2}{|c|}{$\mathrm{P}=0.02$} & \multicolumn{2}{|c|}{$X^{2}=1.6$} & \multicolumn{2}{|c|}{$\mathrm{P}=0.20$} \\
\hline Sürekli ilaç k & lurumu & & & & & & & \\
\hline Var & 13 & 25.0 & 39 & 75.0 & 14 & 26.9 & 38 & 73.1 \\
\hline Yok & 42 & 27.6 & 110 & 72.4 & 47 & 30.9 & 105 & 69.1 \\
\hline & & & & & & & & \\
\hline Toplam & 55 & 27.0 & 149 & 73.0 & 61 & 29.9 & 143 & 70.1 \\
\hline
\end{tabular}


Tablo 7. İşyeri ortam faktörlerine göre pestisit satış yerlerinde çalışanlarda nörolojik ve psikiyatrik semptom durumu

\begin{tabular}{|c|c|c|c|c|c|c|c|c|}
\hline \multirow{3}{*}{ Değiş̧kenler } & \multicolumn{4}{|c|}{ Nörolojik Semptom $(\mathrm{Q} / 16)$} & \multicolumn{4}{|c|}{ Psikiyatrik Semptom (GSA/12) } \\
\hline & \multicolumn{2}{|c|}{6 ve üzeri } & \multicolumn{2}{|c|}{5 ve altı } & \multicolumn{2}{|c|}{ Semptom var } & \multicolumn{2}{|c|}{ Semptom yok } \\
\hline & Sayı & Yüzde & Sayı & Yüzde & Sayı & Yüzde & Sayı & Yüzde \\
\hline \multicolumn{9}{|c|}{ Satış yerinin etrafında ev ve işyeri bulunma durumu } \\
\hline Evet & 48 & 24.1 & 143 & 74.9 & 58 & 30.4 & 133 & 69.6 \\
\hline \multirow[t]{2}{*}{ Hayır } & 2 & 50.0 & 2 & 50.0 & 1 & 25.0 & 3 & 75.0 \\
\hline & \multicolumn{2}{|c|}{ Fisher Exact Test } & \multicolumn{2}{|c|}{$\mathrm{p}=0.27$} & \multicolumn{2}{|c|}{ Fisher Exact Test } & \multicolumn{2}{|c|}{$\mathrm{P}=1.00$} \\
\hline \multicolumn{9}{|c|}{ Çok zehirli raf ve bölmelerde 'Çok Zehirli Bitki Koruma Ürünleri' ifadesi bulunma durumu } \\
\hline Evet & 6 & 24.0 & 19 & 76.0 & 9 & 36.0 & 16 & 64.0 \\
\hline \multirow[t]{2}{*}{ Hayır } & 44 & 25.9 & 126 & 74.1 & 50 & 29.4 & 120 & 7.6 \\
\hline & \multicolumn{2}{|c|}{$\mathrm{X}^{2}=0.0$} & \multicolumn{2}{|c|}{$\mathrm{p}=1.00$} & \multicolumn{2}{|c|}{$\mathrm{X}^{2}=0.4$} & \multicolumn{2}{|c|}{$\mathrm{p}=0.49$} \\
\hline \multicolumn{9}{|c|}{ Atık suların giderilmesi için kanalizasyon tertibatı } \\
\hline Evet & 21 & 21.6 & 76 & 78.4 & 30 & 30.9 & 67 & 69.1 \\
\hline \multirow[t]{2}{*}{ Hayır } & 29 & 29.6 & 69 & 70.4 & 29 & 29.6 & 69 & 70.4 \\
\hline & \multicolumn{2}{|c|}{$X^{2}=1.6$} & \multicolumn{2}{|c|}{$\mathrm{p}=0.25$} & \multicolumn{2}{|c|}{$X^{2}=0.0$} & \multicolumn{2}{|c|}{$\mathrm{p}=0.87$} \\
\hline \multicolumn{9}{|c|}{ İlaçlamada kullanılan koruyucu ekipman satışı } \\
\hline Evet & 2 & 10.5 & 17 & 89.5 & 7 & 36.8 & 12 & 63.2 \\
\hline \multirow[t]{2}{*}{ Hayır } & 48 & 27.3 & 128 & 72.7 & 52 & 29.5 & 124 & 70.5 \\
\hline & Fisher & act Test & & & & & & \\
\hline $\begin{array}{l}\text { Satış yerinde } \\
\text { Çevre İçin Zel }\end{array}$ & $\begin{array}{l}\text { görüle } \\
\text { likelidir }\end{array}$ & $\begin{array}{l}\text { ecek ve c } \\
\text { adesi bul }\end{array}$ & $\begin{array}{l}\text { nabilec } \\
\text { ma dur }\end{array}$ & $\begin{array}{l}\text { ekilde } ' t \\
\text { u }\end{array}$ & i Korur & Ürünleri & 1, Hay & \\
\hline Evet & 14 & 33.3 & 27 & 66.7 & 15 & 35.7 & 27 & 64.3 \\
\hline Hayır & 36 & 23.5 & 117 & 76.5 & 44 & 28.8 & 109 & 71.2 \\
\hline & & & & & & & & \\
\hline Yangın söndi & i bulun & durumu & & & & & & \\
\hline Evet & 28 & 26.9 & 76 & 73.1 & 35 & 33.7 & 69 & 66.3 \\
\hline Hayır & 22 & 24.2 & 69 & 75.8 & 24 & 26.4 & 67 & 73.6 \\
\hline & & & & & & & & \\
\hline Zararlı kokul & Imesi iç & havalanc & na düz & oulunma & rumu & & & \\
\hline Evet & 21 & 31.8 & 45 & 68.2 & 23 & 34.8 & 43 & 65.2 \\
\hline Hayır & 29 & 22.5 & 100 & 77.5 & 35 & 27.1 & 94 & 72.9 \\
\hline & & & & & & 1.2 & & \\
\hline Bitki koruma & olum & etkileri & naruz & nmama & $\mathrm{n} \mathrm{mul}$ & zalı oda & ma d & \\
\hline Evet & 31 & 24.4 & 96 & 75.6 & 42 & 33.1 & 85 & 66.9 \\
\hline Hayır & 19 & 27.9 & 49 & 72.1 & 17 & 25.0 & 51 & 75.0 \\
\hline & & & & & & 1.4 & & \\
\hline
\end{tabular}


Tablo 7. (Devamı)

\begin{tabular}{|c|c|c|c|c|c|c|c|c|}
\hline \multirow{3}{*}{ Değiş̧kenler } & \multicolumn{4}{|c|}{ Nörolojik Semptom (Q/16) } & \multicolumn{4}{|c|}{ Psikiyatrik Semptom (GSA/12) } \\
\hline & \multicolumn{2}{|c|}{6 ve üzeri } & \multicolumn{2}{|c|}{5 ve altı } & \multicolumn{2}{|c|}{ Semptom var } & \multicolumn{2}{|c|}{ Semptom yok } \\
\hline & Sayl & Yüzde & Sayl & Yüzde & Sayı & Yüzde & Sayı & Yüzde \\
\hline \multicolumn{9}{|c|}{ Çok zehirli bitki koruma ürünleri için ayrı raf ve bölme bulunma durumu } \\
\hline Evet & 18 & 28.1 & 46 & 71.9 & 21 & 32.8 & 43 & 67.2 \\
\hline \multirow[t]{2}{*}{ Hayır } & 32 & 24.4 & 99 & 75.6 & 38 & 29.0 & 93 & 71.0 \\
\hline & \multicolumn{2}{|c|}{$\mathrm{X}^{2}=0.3$} & \multicolumn{2}{|c|}{$\mathrm{P}=0.57$} & \multicolumn{2}{|c|}{$\mathrm{X}^{2}=0.3$} & \multicolumn{2}{|c|}{$\mathrm{P}=0.58$} \\
\hline \multicolumn{9}{|c|}{ Satış yerinde açıkta satılan ürün bulunma durumu } \\
\hline Evet & 5 & 20.8 & 19 & 79.2 & 6 & 25.0 & 18 & 75.0 \\
\hline \multirow[t]{2}{*}{ Hayır } & 45 & 26.3 & 126 & 73.7 & 53 & 31.0 & 118 & 69.0 \\
\hline & \multicolumn{2}{|c|}{$\mathrm{X}^{2}=0.3$} & \multicolumn{2}{|c|}{$P=0.80$} & \multicolumn{2}{|c|}{$\mathrm{X}^{2}=0.3$} & \multicolumn{2}{|c|}{$\mathrm{P}=0.64$} \\
\hline \multicolumn{9}{|c|}{ Satış yerinde aynı ortamda insan ve hayvan gıdalarının satışı } \\
\hline Evet & 0 & 0.0 & 4 & 100.0 & 0 & 0.0 & 4 & 100.0 \\
\hline \multirow[t]{2}{*}{ Hayır } & 50 & 26.2 & 141 & 73.8 & 59 & 30.9 & 132 & 69.1 \\
\hline & \multicolumn{2}{|c|}{ Fisher Exact Test } & \multicolumn{2}{|c|}{$\mathrm{P}=0.57$} & \multicolumn{2}{|c|}{ Fisher Exact Test } & \multicolumn{2}{|c|}{$\mathrm{P}=0.31$} \\
\hline \multicolumn{9}{|c|}{ Lavaboda sabun bulunma durumu } \\
\hline Evet & 43 & 26.7 & 118 & 73.3 & 54 & 33.5 & 107 & 66.5 \\
\hline \multirow[t]{2}{*}{ Hayır } & 7 & 20.6 & 27 & 79.4 & 5 & 14.7 & 29 & 85.3 \\
\hline & & & & 52 & & 4.7 & & 03 \\
\hline El ve yüz yılká & lavabo & lunma d & $\mathrm{imu}$ & & & & & \\
\hline Evet & 46 & 27.4 & 122 & 72.6 & 56 & 33.3 & 112 & 66.7 \\
\hline Hayır & 4 & 14.8 & 23 & 85.2 & 3 & 11.1 & 24 & 88.9 \\
\hline & & & & 23 & & 5.4 & & \\
\hline Etiketsiz bitk & ürünü s & & & & & & & \\
\hline Evet & 3 & 21.4 & 11 & 78.6 & 4 & 28.6 & 10 & 71.4 \\
\hline Hayır & 47 & 26.0 & 134 & 74.0 & 55 & 69.6 & 126 & 30.4 \\
\hline & Fisher & act Test & & .00 & Fishe & zact Test & & \\
\hline Ruhsatsız üri & & & & & & & & \\
\hline Evet & 2 & 33.3 & 6 & 66.7 & 2 & 33.3 & 4 & 66.7 \\
\hline Hayır & 48 & 25.4 & 141 & 74.6 & 57 & 30.2 & 132 & 69.8 \\
\hline & Fisher & act Test & & 64 & Fishe & ract Test & & \\
\hline Kullanma sür & ş bitki k & uma ürü & satışı & & & & & \\
\hline Evet & 16 & 31.4 & 35 & 68.6 & 13 & 25.5 & 38 & 74.5 \\
\hline Hayır & 34 & 23.6 & 110 & 76.4 & 46 & 31.9 & 98 & 68.1 \\
\hline & & & & 35 & & 0.7 & & \\
\hline Toplam & 55 & 27.0 & 149 & 73.0 & 61 & 29.9 & 143 & 70.1 \\
\hline
\end{tabular}


Tablo 8. nörolojik ve psikiyatrik semptomlarla ilişkisi saptanan değișkenlerin regresyon analizi sonuçları

\begin{tabular}{|c|c|c|c|c|}
\hline Değişkenler & B & $\mathrm{P}$ & $\mathrm{OR}^{*}$ & $\% 95 \mathrm{GA}^{* *}$ \\
\hline \multicolumn{5}{|l|}{ Nörolojik Semptom } \\
\hline Doktor tanılı hastalığı olan & 0.6 & 0.06 & 1.9 & $0.9-3.7$ \\
\hline Pestisit uygulayan & 0.8 & 0.02 & 2.3 & $1.1-4.9$ \\
\hline $\begin{array}{l}\text { Pestisit satış yerinde } 60 \text { ay ve } \\
\text { üzerinde çalışan }\end{array}$ & 0.9 & 0.00 & 2.5 & $1.3-4.9$ \\
\hline Sabit & -0.4 & 0.26 & & \\
\hline
\end{tabular}

Hosmer - Lemeshow: 0.57

Psikiyatrik Semptom

\begin{tabular}{lcccc}
\hline İşyerinde lavabo bulunan & 0.9 & 0.34 & 2.5 & $0.4-17.6$ \\
Lavaboda sabun bulunan & -0.0 & 0.94 & 0.9 & $0.2-5.3$ \\
$\begin{array}{l}\text { Pestisit satış yerinde } 60 \text { ay ve } \\
\text { üzerinde çalışan }\end{array}$ & 0.5 & 0.12 & 1.6 & $0.9-3.1$ \\
Lise ve üzerinde öğrenimi olan & 0.8 & $\mathbf{0 . 0 1}$ & $\mathbf{2 . 3}$ & $1.2-4.5$ \\
Sabit & $\mathbf{0 . 2}$ & $\mathbf{0 . 4 3}$ & & \\
\hline
\end{tabular}

Hosmer - Lemeshow:0.54

*Tahmini Rölatif Risk / Odds Ratio, **Güven Aralığı

İlgili yönetmeliğin $12 ., \quad 13 . \quad$ ve 14 . maddelerinde bitki koruma ürününün perakende ya da toptan satışını yapan işyerlerinin ve depoların sağlaması gereken şartlar belirtilmektedir. Buna göre; bitki koruma ürünlerinin olumsuz etkilerine maruz kalınmaması için satış yerlerinde muhafazalı bir oda, zararlı kokuların giderilmesi için havalandırma düzeni, el ve yüz yıkanabilecek su ve lavabo tertibatı, yeterli oranda yangın söndürme cihazı, ilk bakıșta görülebilecek ve okunabilecek şekilde "bitki koruma ürünleri insan, hayvan ve çevre için zehirli ve tehlikelidir." ifadesi, çok zehirli bitki koruma ürünleri için özel raf ve bölmeler ve bu bölmelerde "çok zehirli bitki koruma ürünleri" ibaresi bulunması gerekmektedir. Satış yerleri, apartman katlarında, çevresine zarar verebilecek ev ve işyerleri arasında olmamalıdır. Bayilerin her ne suretle olursa olsun insan ve hayvan ilaçları ile gıdalarını satmaması ve bitki koruma ürünleri ile bir arada bulundurmaması gerekmektedir. ${ }^{29} \mathrm{Bu}$ çalışmada, yaklaşık üç işyerinden birinde zararlı kokuların giderilmesi için havalandırma, 10 işyerinden dokuzunda su ve lavabo tertibatı, iki işyerinden birinde yangın söndürme cihazı, beş işyerinden birinde satış yerinde ilk bakışta görülebilecek ve okunabilecek șekilde "bitki koruma ürünleri insan, hayvan ve çevre için zehirli ve tehlikelidir" ifadesi, üç işyerinden birinde çok zehirli bitki koruma ürünleri için ayrı raf ve bölme bulunmaktadır. Kara ve Şimşek'in ${ }^{30}$ tüm GAP Bölgesi'ndeki çalışmasında bu oranlar sırasıyla \%79.9, \%91.4, \%71.1, \%45.0, \%81.1'dir. Çalışmalar arasındaki iş yeri ortam faktörleri 
arasındaki bu farklılığın, bölgesel farklılıklardan ve gelişmişlik düzeylerinden etkilendiği düşünülebilir. ${ }^{31}$

18.04.2014 tarihli ve 28976 sayll resmi gazetede yayınlanan "İş Sağlığı ve Güvenliğine İlişkin İşyeri Tehlike Sınıfları Tebliğinde Değişiklik Yapılmasına Dair Tebliğ"e göre "Bitkisel üretimi destekleyici ilaçlama ve zirai mücadele faaliyetleri (zararlı otların imhası dahil, hava yoluyla yapılanlar hariç)" adıyla pestisit uygulamasının çok tehlikeli işler sınıfında olduğu belirtilmiștir.32 "Bitki Koruma Ürünlerinin Uygulama Usul ve Esaslarına Dair Yönetmelik" uygulayıcıların, çevrenin ve diğer canlıların korunması ile ilgili usul ve esasları belirlemektedir. Yönetmeliğin 4. maddesi gereğince; pestisit işlerinde, 18 yaşını bitirmemiş genç işçilerin çalıştırılamayacağ ifade edilmekle birlikte, 16 yaşını doldurmuş ancak 18 yaşını doldurmamışların en az altı ayda bir, 18 yaşından büyüklerin ise en az yılda bir defa hekim raporu almaları istenmiştir. ${ }^{33} \mathrm{Bu}$ çalışmada, uygulayıcı olarak görev yapanların yaşı yönetmeliğe göre uygun olmakla beraber, sadece 10 kişiden biri yönetmelikte belirtilen işe giriş muayenesini ve rutin kontrollerini yaptırmıştır.

İnsanların pestisit uygulama zamanına ve hangi ürünün uygulanacağına karar verme şekilleri bireysel farklılıklar göstermektedir. Kendi deneyimlerine göre, diğer tarım çalışanlarının deneyimlerine göre, ziraat mühendisi tavsiyesine göre, tarım ofisi ya da bakanlığın önerilerine göre, bayilerin önerilerine göre, medya ya da komşu fikirlerine göre bu davranışlarlar şekillenmektedir. ${ }^{34-43} \quad \mathrm{Bu}$ çalışmada da, ilaç seçimini yapan kişinin çoğunlukla işyerindeki yetkili kişi olduğu ifade edilmiştir. Uygulama işlerinde çalışan yaklaşık her 3 kişiden biri yönetmelik tarafından belirtilen mesleki açıdan yeterli eleman olmasına rağmen, her 10 kişiden dokuzu ilacın seçimini yapanın yetkili kişi olduğunu belirtmiştir. Zyoud ve arkadaşlarının ${ }^{44} 2010$ yılında yaptıkları bir çalışmada, katılımclların \%30'ı kendi deneyimlerine göre, \%21'i ziraat mühendisi ya da uzman önerilerine göre, $\% 15$ 'i tarım ofisi ya da bakanlığın önerilerine göre, \%24'ü pestisit bayisinin önerilerine göre pestisit uygulama zamanına ve ürününe karar vermektedir. Salameh ve arkadaşlarının ${ }^{41}$ yaptıkları bir çalışmada ise yine aynı konu incelendiğinde; katılımcların \%45'inin kendi deneyimlerine göre, \%30'unun ziraat mühendisi ya da uzman önerilerine göre, \%23'ünün pestisit bayisinin önerilerine göre pestisit uygulama zamanına ve ürününe karar verdikleri saptanmıştır.

$\mathrm{Bu}$ çalışmada, pestisit satış yerlerinde çalışan yaklaşık her üç kişiden birinde "Q16 Nörolojik Değerlendirme Ölçeği"ne göre nörolojik semptom saptanmıştır. Birçok çalışmada da nörolojik bozukluk ile pestisit etkilenimi arasında ilişki saptanmıştır. ${ }^{45-47} \mathrm{Bu}$ çalışmada, ilaçlama işlerinde çalışanlarda ve satış yerinde çalışma süresi 60 ay ve üzeri olanlarda nörolojik semptom sıklığı daha yüksek bulunmuştur. Khan ve arkadaşlarının ${ }^{45} 2014$ yılında pestisitlerin nörolojik etkileri üzerine yaptıkları bir çalışmada, ilaçlama işlerinde çalışanlarda çalışmayanlara göre benzer şekilde nörolojik semptomların daha yüksek olduğu saptanmıştır. Özellikle bilişsel, davranışsal otonomik, motor ve duyusal problemler daha fazla görülmüştür. ${ }^{45}$ Butinof ve arkadaşlarının ${ }^{46}$ 2015 yılında yaptıkları kesitsel araștırmada, bu çalışmaya benzer şekilde baş ağrısı sıklığı yüksek bulunmuştur. Labbafinejad ve arkadaşlarının $^{47}$ 2013'te ev içindeki organik solventlere maruz kalan işçilere Q16 ölçeğini uygulamışlar, puan ortalamasını organik solventlere maruz kalanlarda (4.8 \pm 4.4), kalmayanlardan (3.2 \pm 3.1) daha yüksek bulmuşlardır ve aradaki fark istatistiksel olarak da anlamlıdır ( $\mathrm{p}=0.001)$. Bizim çalışmamızda da, puan ortalaması satış yerlerinde çalışanlarda $3.28 \pm 3.03$, satış işlerine ek olarak ilaçlama işlerinde de çalışanlarda $4.30 \pm 3.72$ olup, aradaki fark istatistiksel olarak da anlamlıdır $(\mathrm{p}<0.05)$.

Çalışanların pestisitlere bağlı polinöropati açısından incelenmesi amacıyla, nörolojik tarama testi sonucu risk tespit edilen 55 kiși (Q 16 Testi 6 puan ve üzeri olanlar ya da iğnelenme, karıncalanma gibi nöropati semptomları gösterenler) ve asetikolinesteraz enzimi merkez laboratuvara göre düşük tespit edilen altı kişi nöropati gelişimi açısından risk altında kabul edilerek 61 kişiye EMG (Polinöropati protokolü) uygulanması planlanmış, riskli görülenlerin \%73.8'ine ulaşılarak, EMG uygulanmış ve değerlendirilmiştir. EMG sonuçlarına göre polinöropati tanısı konan çalışan olmamıştır. Ancak; nöropatinin ince lif, kalın lif ve otonom nöropati gibi çeşitleri bulunmaktadır ve bu 
çalışmada değerlendirilen kalın lif nöropatilerdir. Periferik sinir lifleri incelemeleri, polinöropati tanısında çok önemli olmakla birlikte, seçici olarak miyelinli liflerin hasarlanmalarını göstermesi, küçük çaplı miyelinsiz lifleri değerlendirmek için kullanılan metodların rutin nörofizyolojide kullanımının olmaması nedeniyle var olan bir polinöropati saptanamamış olabilir. 48

$\mathrm{Bu}$ çalışmaya göre, pestisit satış yerinde çalışan yaklaşık her üç kişiden biri psikiyatrik semptom yaşamaktadır. Beard ve arkadaşları ${ }^{49}$ 2014'te yaptıkları çalışmalarında, 1993- 1997 yılları arasında 10 pestisit sinıfinda ve 50 spesifik pestisit kullanıcısı 21.208 pestisit uygulayıcısı üzerinde, pestisite maruz kalma ile depresyonun ilişkili olduğunu saptamışlardır. Beseler ve arkadaşlarl ${ }^{50}$ pestisit etkilenimi ve depresyon arasındaki ilişkiyi inceledikleri bir çalışmalarında, pestisit zehirlenmesi gibi güçlü pestisit etkilenimi olanlarda depresyon sıklığını yüksek bulmuşlardır. Bizim çalışmamızın ikili analizlerinde de 60 ay ve üzerinde pestisit satış yerinde çalışanlarda psikiyatrik semptom varlığı yaklaşık iki kat yüksek bulunmuştur. Çalışmada öğrenim düzeyi düştükçe psikiyatrik semptom görülme sıklı̆̆ da düşmektedir. Bu durum, eğitimle birlikte kişilerin farkındalığının artmasiyla daha fazla semptom bildirmeleriyle açıklanabilir.

Sonuç olarak;

1. Bu çalışma, ülkemizde pestisit satış yerlerinde çalışanların nöro-psikiyatrik semptomlarını değerlendiren ilk araştırma niteliğindedir.

2. Araştırma bulguları, yasal düzenlemelere tam uygun Şanlıurfa il merkezine kayıtlı pestisit satış yeri olmadığını göstermektedir. Sözkonusu düzenlemeler toplum ve çalışan sağlığını korumak için ortam faktörlerinin düzenlenmesine ve "Bitki Koruma Ürünleri İnsan, Hayvan ve Çevre İçin Zehirli ve Tehlikelidir" levhaları ile toplumda farkındalık oluşturmaya yöneliktir. İşyerlerinin yasal düzenlemelere uygun hale getirilmesi için gerekli eğitim, destek ve denetim çalışmalarının sürekli yapılması önerilmektedir. Pestisit satış yerlerindeki çalışanların eğitimi, sağlık izlemlerinin yapılması ve ortam faktörlerinin iyileștirilmesine yönelik Il Sağlık
Müdürlükleri'nin aktif rol alması uygun olacaktır.

3. Araştırmada her üç kişiden birinde nöro-psikiyatrik semptom saptanmıştır. Mesleki etkilenimi azaltmak/ ortadan kaldırmak için risk faktörlerinin kontrolü yanı sıra, ikincil koruma kapsamında taramaların yapılması gereklidir. Satış yerinde çalışanların düzenli izlenmesi, nöro-psikiyatrik taramalarının yapılması, kişilerde sağlıklı davranış geliştirmek için eğitim ve danışmanlık yapılması önerilmektedir. "Aile Hekimliği Uygulama Yönetmeliği”nin 4. maddesinde periyodik sağlık muayenesi yapmak ve kendisine kayıtlı kişileri yılda en az bir defa değerlendirerek sağlık kayıtlarını güncellemek Aile Sağlığı Merkezi'nin görev ve yetkileri arasındadır. 51

4. Tarımsal üretimde verimi artırmak için hızla artan pestisit kullanımının kontrolünü sağlamada, Halk Sağlığı Müdürlükleri, Gıda, Tarım ve Hayvancılık Müdürlükleri ve ilgili diğer sektörlerin yasal düzenlemelerde belirtilen halk sağlığı programlarını yapabilmeleri için işbirliği yapmaları uygun olacaktır.

5. Özellikle pestisit satış yerinde çalışanlarda ve uygulayıcılarda sağlık eğitimi ve denetim başta olmak üzere halk sağlığ programlarının kanıta dayalı geliştirilebilmesi açısından; benzer yöntemlerle farklı gruplarda nöro-psikiyatrik semptomların ölçülmesi, ayrıca kohort çalışmalarıyla asetilkolinesteraz enzim düzeyinin izlenmesi ve ölçeklerin tekrar uygulanmasının kanıtları artıracağını düşündürmektedir.

\section{Kaynaklar}

1. Erdoğan BY. Samsun'da yaygın olarak kullanılan pestisitlerin sağlığa ve çevreye etkileri. Alınteri 2010;19(B):28-35.

2. Çevre Sağlı̆̆ı, Pestisitler, Milli Eğitim Bakanlığı, 850CK0054, Ankara, 2012.

Erişim yeri: http://megep.meb.gov.tr/ mte_program_modul/moduller_pdf/Pestisitler.p df Erişim Tarihi: 03.07.2018.

3. T.C. Resmi Gazete. Türk Gida Kodeksi Pestisitlerin Maksimum Kalıntı Limitleri Yönetmeliği. Resmi Gazete Sayısı: 29899, 25 Kasım 2016. 
Erişim yeri: http://www.resmigazete.gov.tr/ eskiler/2016/11/20161125M1-1.htm Erișim Tarihi: 29.06.2018.

4. T.C. Resmi Gazete. Bitki Koruma Ürünleri Kontrol Yönetmeliği. Resmi Gazete Sayısı: 27939, 20.05.2011.

Erişim yeri: http://www.resmigazete.gov.tr/ eskiler/2011/05/20110520-2.htm Erişim Tarihi:29.06.2018.

5. Robert RJ, Reigart JR. Recognition and management of pesticide poisining. Washington: 6. Baskl, 2013

6. Donham KJ, Thelin A. health effects of agricultural pesticides. Agricultural Medicine: Occupational and Environmental Health for the Health Professions. 2006;173-198.

7. George J, Shukla Y. Early changes in proteome levels upon acute Deltamethrin exposure in mammalian skin system associated with its neoplastic transformation potential. $J$ Toxicol Sci 2013;38(4):629-642.

8. Hou L, Andreotti G, Baccarelli AA, Savage S, Hoppin JA, Sandler DP, Barker J, Zhu Z, Hoxha M, Dioni L, Zhang X, Koutros S, Freeman LEB, Alavanja MC. Lifetime pesticide use and telomere shortening among male pesticide applicators in the agricultural health study. Environ Health Perspect 2013;121(8):919-924.

9. Xu XJ, Su JG, Bizzarri AR, Cannistraro S, Liu M, Zeng Y, Chen WZ, Wang CX. Detection of persistent organic pollutants binding modes with androgen receptor ligand binding domain by docking and molecular dynamics. BMC Struct Biol 2013;13:16.

10. Gaytán BD, Loguinov AV, Lantz SR, Lerot JM, Denslow ND, Vulpeve CD. Functional profiling discovers the dieldrin organochlorinated pesticide affects leucine availability in yeast. Toxicol Sci. 2013;132(2):347-358.

11. Budnik LT, Kloth S, Baur X, Preisser AM, Schwarzenbach $H$. Circulating mitochondrial DNA as biomarker linking environmental chemical exposure to early preclinical lesions elevation of mtDNA in human serum after exposure to carcinogenic halo-alkane-based pesticides. PLoS One 2013;8(5):e64413.

12. Koutros S, Berndt SI, Hughes Barry K, Andreotti G, Hoppin JA, Sandler DP, Yeager M, Burdett LA, Yuenger J, Alavanja MCR, Freeman
LEB. Genetic susceptibility loci, pesticide exposure and prostate cancer risk. PLoS One 2013;8(4):e58195.

13. Ye M, Beach J, Martin JW, Senthilselvan A. Occupational pesticide exposures and respiratory health. Int J Environ Res Public Health 2013;10(12):6442-6471.

14. Navaranjan G, Hohenadel K, Blair A, Demers PA, Spinelli JJ, Pahwa P, McLaughlin JR, Dosman JA, Ritter L, Harris SA. Exposures to multiple pesticides and the risk of Hodgkin Lymphoma in Canadian men. Cancer Causes Control 2013;24:1661-1673.

15. Sexton K, Salinas JJ, McDonald TJ, Gowen RMZ, Miller RP, McCormick, JB, Fisher-Hoch SP. Biomarkers of maternal and fetal exposure to organochlorine pesticides measured in pregnant hispanic women from brownsville, Texas. Int $J$ Environ Res Public Health 2013;10(1):237-248.

16. Buralli RJ, Ribeiro H, Mauad T, AmatoLourenço LF, Salge JM, Diaz-Quijano FA, Leão RS, Marques RC, Silva DS, Guimarães JRD. Respiratory condition of family farmers exposed to pesticides in the state of Rio de Janeiro, Brazil. Int J Environ Res Public Health.2018;15(6).pii: E1203.

17. Zhang C, Sun $Y$, Hu R, Huang J, Huang X, Li Y, Yin Y, Chen Z. A comparison of the effects of agricultural pesticide uses on peripheral nerve conduction in China. Scientific Reports 2018;8(1):9621.

18. Lyu CP, Pei JR, Beseler LC, Li YL, Li JH, Ren M, Stallones L, Ren SP. Case control study of Impulsivity, aggression, pesticide exposure and suicide attempts using pesticides among farmers. Biomed Environ Sci. 2018;31(3):242246.

19. Cherry N, Beach J, Senthilselvan A, Burstyn I. Pesticide use and asthma in alberta grain farmers. Int $J$ Environ Res Public Health. 2018;15(3).pii: E526.

20. Priyadharshini UK, Latha R, Kavitha U, Nirmala N. Effects of organophosphorus pesticides on cardiorespiratory parameters among the farmers. J Clin Diagn Res 2017;11(9):CC01-CC04.

21. Ağar S, Aydınoğlu H, Temel O, İkizünal K, Ece H. Pestisit kullanımının tarihçesi, bugünü ve 
geleceği. Türkiye Entomoloji Dergisi 1991;15(4):247-256.

22. T.C. Resmi Gazete. Zirai Mücadele ve Karantina Kanunu Kanun no: 6968, 1957. Resmi Gazete Sayısı: 9615, 24.05.1957.

Erişim yeri: http://www.zmo.org.tr/mevzuat/ mevzuat_detay.php?kod=93 Erişim Tarihi:29.06.2018.

23. T.C. Resmi Gazete. Bitki Koruma Ürünlerinin Toptan ve Perakende Satılması İle Depolanması Hakkında Yönetmelik. Resmi Gazete Sayısı: 26670, 11.10.2007.

Erişim yeri: http://www.resmigazete.gov.tr/ eskiler/2007/10/20071011-11.htm Erişim Tarihi:29.06.2018.

24. Field WE, Tormoehlen RL. Education and training as intervention strategies (Eds. James E. Lessenger). Agricultural Medicine; A practical guide. 2006;42-51.

25. Benek S. Şanlıurfa ilinin tarımsal yapısı, sorunları ve çözüm önerileri. Coğrafi Bilimler Dergisi 2006;4(1):67-91.

26. Şimşek Z, Koruk İ, Akbaba M, Kakillioğlu T. Şanlıurfa'da 2009 yılında kullanılan pestisit tür ve miktarları. 1. Ulusal Biyosidal Kongresi, 4-7 Kasım 2010 Antalya. Ss:29.

27. Kılıç C. Genel sağlık anketi: güvenilirlik ve geçerlilik çalışması, Türk Psikiyatri Dergisi 1996;7(1).

28. Beheshti S, Sharifian S.A., Mehrdad R, Hosseininia SH. Solvent exposure can cause neurobehavioral effect. J Gorgan Uni Med Sci 2002;4(2):30-35.

29. T.C. Resmi Gazete. Bitki Koruma Ürünlerinin Toptan ve Perakende Satılması ile Depolanması Hakkında Yönetmelik. Resmi Gazete Sayısı: 27870, 10.03.2011.

Erişim yeri: http://mevzuat.basbakanlik.gov.tr/ Metin.Aspx?MevzuatKod=7.5.14790\&sourceXml Search $=\&$ MevzuatIliski $=0 \quad$ Erişim Tarihi:29.06.2018.

30. Kara B, Şimşek Z. Güneydoğu Anadolu Bölgesi'nde pestisit satıș yerlerinin yasal düzenlemelere uygunluk durumunun değerlendirilmesi. Turk J Public Health 2016;14(1).
31. TNSA 2013. Hacettepe Üniversitesi Nüfus Etütleri Enstitüsü Ankara, Türkiye.

Erişim yeri: www.hips.hacettepe.edu.tr Erişim Tarihi:03.07.2018.

32. T.C. Resmi Gazete. İș Sağlığı ve Güvenliğine İlişkin İşyeri Tehlike Sınıfları Tebliğinde Değişiklik Yapılmasına Dair Tebliğ. Resmi Gazete Sayısi: 28976, 18.04.2014.

Erişim yeri: http://resmigazete.gov.tr/eskiler/ 2014/04/20140418-17.htm Erişim Tarihi: 03.07.2018.

33. T.C. Resmi Gazete. Bitki Koruma Ürünlerinin Uygulama Usul ve Esaslarına Dair Yönetmelik. Resmi Gazete Sayısı: 27880, 20.03.2011.

Erișim yeri: http://www.resmigazete.gov.tr/ eskiler/2011/03/20110320-1.htm Erișim Tarihi: 03.07.2018.

34. Atreya K. Pesticide use knowledge and practices: A gender differences in Nepal. Environmental Research 2007;104,305-311.

35. Jors E, Morant RC, Aguilar GC, Huici O, Lander F, Bælum J, Konradsen F. Occupational pesticide intoxications among farmers in Bolivia: A cross-sectional study. Environ Health 2006;5:10.

36. Palis FG, Flor RJ, Warburton H, Hossain M. Our farmers at risk: Behaviour and belief system in pesticide safety. Journal of Public Health 2006;28(1),43-48.

37. Ribeiro MG, Colasso CG, Monteiro PP, Filho WRPF ve ark. Occupational safety and health practices among flower greenhouses workers from Alto Tietê region (Brazil). Science of the Total Environment 2012;416:121-126.

38. Mohanty MK, Behera BK, Jena SK, Srikanth S ve ark. Knowledge attitude and practice of pesticide use among agricultural workers in Puducherry, South India. Journal of Forensic and Legal Medicine 2013;20:1028e1031.

39. Mathews G, Wiles T, Baleguel P. A survey of pesticide application in Cameroon. Crop Protection 2003;22,707-714.

40. Waichman AV, Eve E, da Silva Nina NC. Do farmers understand the information displayed on pesticide product labels? A key question to reduce pesticides exposure and risk of poisoning in the Brazilian Amazon. Crop Protection 2007;26:576-583. 
41. Salameh PR, Balhi I, Brochard P, Saleh A. Pesticides in Lebanon: A knowledge, attitude, and practice study. Environmental Research 2004;94:1-6.

42. Ntow W, Gijzen HJ, Kelderman P, Drechsel P. Farmer perceptions and pesticide use. Pest Manag Sci. 2006;62(4):356-365.

43. Abang AF, Kouame CM, Abang M, Hannah R, Fotso A. Vegetable growers perception of pesticide use practices, cost, and health effects in the tropical region of Cameroon. International journal of Agronomy and Plant Production. 2013;4(5):873-883.

44. Zyoud SH, Sawalha AF, Sweileh WM, Awang R, Al-Khalil SI, Al-Jabi SW, Bsharat NM. Knowledge and practices of pesticide use among farm workers in the West Bank, Palestine: Safety implications. Environ Health Prev Med 2010;15(4):252-261.

45. Khan $\mathrm{K}$, İsmail $\mathrm{AA}$, Rasoul GA, Bonner MR, Lasarev MR, Hendy O, Al-Batanony M, Crane AL, Singleton ST, Olson JR, Rohlman DS. Longitudinal assessment of chlorpyrifos exposure and selfreported neurological symptoms in adolescent pesticide applicators. BMJ Open 2014;4:e004177.

46. Butinof $M$, Fernandez RA, Stimolo MI, Lantieri MJ, Blanco M, Machado AL, Franchini G, Díaz Mdel P. Pesticide exposure and health conditions of terrestrial pesticide applicators in
Córdoba Province, Argentina. Cad. Saúde Pública 2015;31(3):633-646.

47. Labbafinejad $\mathrm{Y}, \quad$ Mohammadi $\mathrm{S}$, Mirzamohammadi E, Ghaffari M, Attarchi M, Amiri A. Assessment of neurobehavioral disorders in workers exposed to organic solvents in a publication house. Med J Islam Repub Iran 2014;28:3.

48. Karam C, Dyck PJ. Toxic Neuropathies. Semin Neurol. 2015;35(4):448-457.

49. Beard JD, Umbach DM, Hoppin JA, Richards M, Alavanja MCR, Blair A,Sandler DP, Kamel Fve ark. Pesticide exposure and depression among male private pesticide applicators in the agricultural health study. Environ Health Perspect. 2014;122(9):984-991.

50. Beseler CL, Stallones L, Hoppin JA, Alavanja MCR, Blair A, Keefe T, Kamel F. Depression and pesticide exposures among private pesticide applicators enrolled in the agricultural health study. Environ Health Perspect. 2008; 116(12):1713-1719.

51. T.C. Resmi Gazete. Aile Hekimliği Uygulama Yönetmeliği. Resmi Gazete Sayısı: 28539, 25.01.2013. Erişim yeri: http://ailehekimligi.gov.tr/images/ stories/Mevzuat/Aile_Hekimligi_Uygulama_Yone tmeligi_25_Ocak_2013.pdf Erişim Tarihi: 03.07.2018. 